ing, ${ }^{151621}$ and although patients vary considerably in their response $^{18}$ it does not often produce postural or exertional hypotension. But in perhaps one patient in five or six, particularly those with rather high blood-pressure, ${ }^{12}$ methyldopa does not provide adequate control. Some patients become tolerant to the drug. The frequency of this varies in different reports, ${ }^{19}$ but it is less of a problem than with ganglion-blocking drugs or guanethidine.

Most patients given methyldopa experience some unwanted effects, ${ }^{17} 19$ but the commonest of these, drowsiness, usually lasts only a few days. Other frequent unwanted effects ${ }^{24}$ are dryness of the mouth and inversion of sleep rhythm. Less common but more important are several shared with other hypotensive drugs; these include depression, stuffy nose, troublesome diarrhoea, and fluid retention, which may be serious if heart failure is precipitated. ${ }^{12}$ Fever and occasionally altered responses to tests of liver function are rare but serious toxic effects. In most recorded series treatment with methyldopa has had to be discontinued in perhaps one-third of patients either because of failure to control the bloodpressure or because of unwanted effects. In the remainder reasonable control of pressure has been achieved.

Methyldopa's principal advantages are thus its control of blood-pressure in both lying and standing positions, freedom from postural and exertional swings in pressure, which often make treatment with guanethidine difficult, and the fact that exact dosage appears to be less critical than with other drugs. ${ }^{18}$ Its main disadvantages are its failure to control blood-pressure in some patients, the high frequency of unwanted effects, however mild some may be, and the large number of tablets needed-up to nine or twelve a day for some patients. This could presumably be remedied by the production of a $500-\mathrm{mg}$. tablet in addition to the present one of $250 \mathrm{mg}$. There would seem few contraindications to the use of the drug, though it is not the first choice in malignant hypertension and probably should not be given to patients with a previous history of depression. Its use in combination with other drugs requires further study, though thiazide diuretics certainly potentiate its action, ${ }^{12}$ and may also be needed to control fluid retention. ${ }^{12}$ The main problem is to decide whether treatment is needed at all. Certainly there are still too many patients with high blood-pressure, most of them elderly, who suffer more from their treatment than they would from the untreated disease. \footnotetext{
Schottstaedt, M. F., and Sokolow, M., Amer. Heart F., 1953, 45, 331.
Kincaid-Smith, P., McMichael, J., and Murphy, E. A., Quart. F. Med., $1958,27,117$.

- Montuschi, E., and Pickens, P. T., Lancet, 1962, 2, 897.

- Peart, W. S., and MacMahon, M. T., Brit. med. F., 1964, 1, 398.

- Lawrie, T. D. V., Lorimer, A. R.o McAlpine, S. G., and Reinert, H., ibid., 1964, 1, 402.

- Bechgaard, P., Acta med. scand., 1946, Suppl. No. 172.

Leishman, A.' W. D., Brit. med. F., 1959, 1, 1361.

- Hodge, J. V., McQueen, E. G., and Smirk, H., ibid., 1961, 1, 1.

- Leishman, A. W. D., Lancet, 1963, 1, 1284.

10 Smirk, H., and Hodge, J. V., Brit. med. F., 1963, 2, 1221.

11 Irvine, R. O. H., O'Brien, K. P., and North, J. D. K., Lancet, 1962, 1, 300

12 Dollery, C. T., and Harington, M., ibid., 1962, 1, 759.

12 Onesti, G., Brest, A. N., Novack, P., and Moyer, J. H., Amer. F. Cardiol. $1962,9,863$.

14 Gillespie, L., Oates, J. A., Crout, J. R., and Sjoerdsma, A., Circulation, $1962,25,281$.

15 Bayliss, R. I. S., and Harvey-Smith, E. A., Lancet, 1962, 1, 763.

10 Cannon, P. J., Whitlock, R. T., Morris, R. C., Angers, M., and Laragh, J. H., F. Amer. med. Ass., 1962, 179, 673.

17 Daley, D., and Evans, B., Brit. med. F., 1962, 2, 156.

18 Smirk, H., ibid., $1963,1,146$.

10 Hamilton, M., and Kopelman, H., ibid., 1963, 1, 151

10 Hamilton, M., and Kopelman, H., ibid., 1963, 1, 151.

" L Sheps, S. G., Schirger, A., Osmundson, P. J., and Fairbairn, J. F., f. Amer. med. Ass., 1963, 184, 616.

- Sannerstedt, R., Bojs, G., Varnauskas, E., and Werkö, L., Acta med. scand., 1963, 174, 53.

18 Day, M. D., and Rand, M. J., F. Pharmacol., 1963, 15, 221

"Dollery, C. T., Med. Clin. N. Amer., 1964, 48, 335.
}

\section{Attack on Liver Cancer}

The intra-arterial infusion of drugs to attack cancer cells is being developed in a variety of ways. Recently R. D. Sullivan and his colleagues have reported an ingenious application of their technique of continuous intra-arterial infusion. ${ }^{12}$ Arterial catheters have been inserted, at open operation, into the hepatic artery of 81 patients suffering from advanced cancer of the liver. In 50 of these cases the primary tumour was in the colon or rectum, and in 31 it was in the pancreas, gall-bladder, bile-ducts, stomach, or other organs. In all cases the main disability was hepatic insufficiency. Only a few patients had metastases in organs other than the liver. The prognosis in such cases is very poor, and chemotherapy by ordinary systemic administration is of little value. ${ }^{3}$ The direct administration of drugs through the hepatic artery seemed a feasible approach, because hepatic metastases are nourished from it. Human malignant cells are thought to divide infrequently, sometimes at intervals of three months or more, ${ }^{4}$ so that prolonged exposure to antimitotic drugs is required to destroy them all, because they are likely to be vulnerable during only a limited part of the mitotic cycle.

The catheters are introduced directly to ensure that anomalous hepatic arteries, which are surprisingly frequent, are also catheterized, and to ligate the gastro-duodenal branches, thus sparing the normal gastro-intestinal tissues they supply from the drugs' toxic effects. The drugs have to be forced into the narrow catheters under pressure from a mechanical pump, and out-patients are supplied with a spring-driven pump no larger than a hearing-aid and charged with sufficient drug for continuous administration for five days. They refill it themselves. The catheters are left in situ for long periods, and have been successfully used again 12 months after ligation at the end of a course of treatment Patients supplied with these pumps were able to return home, and some resumed full activity while receiving treatment.

The drugs used were 5-fluorouracil, its riboside (fluorodeoxyuridine), and methotrexate. They were administered for periods of three to six weeks at a time, courses being repeated until maximum clinical benefit was obtained. The liver detoxicates fluorouracil and its riboside, ${ }^{5}$ so that the gastrointestinal tract and the blood system were not damaged Methotrexate is not detoxicated in the liver, but its systemic toxicity could be counteracted by the intramuscular administration of folinic acid. Thus the limiting factor was the toxic effects of the drugs on the liver itself. Sometimes they impaired liver function and caused anorexia and abdominal cramps. Treatment was resumed when tests of the liver function showed improvement.

The results of the treatment were evaluated only in the 73 patients who had received continuous treatment for at least three weeks. An objective response was recorded when the size of the liver regressed by at least $50 \%$, the liver-function tests returned to normal or nearly normal, and clinical benefit ensued, the improvement in each feature being maintained for three months or more. Eighteen of the 29 patients with advanced disease of the liver from primary cancer of the rectum or colon responded, and the average period of survival

\footnotetext{
1 Sullivan, R. D., Miller, E., and Sikes, M. P., Cancer (Philad.), 1959 12,1248 .

2 Zurek, W. Z, 7. Amer. med. Ass., 1965, 194, 481.

s Youn C w et al. Cancer Chemother. Rep., 1960, 6, 17.

- Collins, V. P., Loeffler, R. K., and Tivey, H., Amer. F. Roentgenol. $1956,76,988$.

5 Sullivan, R. D., Norcross, J. W., and Watkins, E., jun., New Engl. I Med., 1964. 270, 321 .

- Young, C. W.. et al Proc. Amer. Ass. Cancer Res., 1960, 3, 164.

- Khubchandani, I. T., f. int. Coll. Surg., 1965, 43, 428.
} 
was 9.4 months, with a range of 3 to 24 months ; seven patients were still alive at the time of reporting. Untreated patients at this stage of the disease would not be expected to survive longer on average than 3.9 months. ${ }^{6}$ Even patients with advanced disease derived some benefit, and a few improved dramatically. Similar results were obtained in the treatment of patients whose disease originated in sites other than the colon, including some with metastatic carcinoid tumours.

Sullivan points out that cancers of the colon and rectum are the most common forms of human neoplasms ; they account for some $15 \%$ of all malignant tumours. ${ }^{7}$ About one-quarter of the patients die from liver failure secondary to hepatic metastases. The new method appears to offer, with little risk, the prospect of prolonging active life to a high proportion of patients. The precise details of management require special skill and familiarity with the properties of highly toxic drugs, and the method is therefore likely to be used mainly in special centres.

\section{Social Salvage}

The basic ingredients of problem families are mental subnormality, temperamental instability, ineducability, a squalid home, and numerous children. Since the main features of this social problem were brought to light by the Family Service Units ${ }^{1}$ and depicted in detail by many medical officers of health, a variety of efforts have been directed towards the alleviation of them and their medical implications. But there is no easy remedy for the difficulties that confront a family with subnormal intelligence in one or both parents, instability of character, intractable ineducability, a squalid home, and neglected children. It is first of all necessary to sort out so far as possible the causes from the consequences.

The Family Service Units which have been set up in various parts of the country tackle the problem by establishing a close relationship between a social worker and the family concerned. This method of intensive casework has yielded results ; it requires dedicated social workers, and each worker can cope with only a relatively small case load. The Family Service Units are well aware of the inherent difficulties, and their primary objectives are to relieve the domestic squalor and give personal help to the mother as well as friendship to all members of the family. Such families have become so socially deprived as to be bereft of friends and moreover to feel completely rejected by society.

It might well be thought that, since the advent of the Welfare State with vast sums now being spent on the health and welfare services, problem families would tend to disappear. Regrettably this has not been so. Their number seems to remain as high as ever. In the big towns the multiple letting of large houses has provided new opportunities for such families to "get lost" among the new slums which have thus come into existence. Medical officers of health, only too well aware of the need to ensure adequate help, make sure that support is readily available for these families, especially when the parents are young and when there is some hope of reversing the downward trend.

\footnotetext{
- McKie, E., Venture in Faith. Liverpool and District Family Service Unit. 1963.

The Aims, Work and Practice of Family Service Units. Sheffield Family Service Unit (1s. net). 1965.
}

Some local authorities employ social workers, special health visitors, and home helps with special training to maintain and assist the problem families. There are hostels where the mothers can go with their children for prolonged periods of training, while the father and perhaps some members of the family are cared for at home by home helps. Many other social and personal services are employed to try to reclaim or at least maintain these feckless people.

The response to assistance by statutory or voluntary bodies varies. Some problem families can be reclaimed; others respond at first but relapse when help is withdrawn, so that some continuing support is required. Regrettably, there is a hard core which does not respond but nevertheless requires considerable permanent support, primarily for the sake of the children. They must be supported to try to prevent the vicious circle from being repeated in the next generation. The Family Service Units in towns where they are active take on a fairly high proportion of these hard-core cases and accept the thankless task of caring for them for prolonged periods.

Recently the Sheffield Unit, in the interests of co-operation between the social services, has produced a booklet setting out the aims, work, and practice of Family Service Units ${ }^{2}$ as a guide to social workers, medical men, and others. In it a problem family is described as one whose habits and ways of life are unacceptable to the community and are apt to lead to the neglect of their children and the break-up of their home. While this description is in general acceptable, the last part of it does not always fit, for often the members of the real problem family, despite their depraved and squalid condition, tend, and want, to remain together.

The Family Service Units started in bomb-stunned Liverpool as a venture in faith, and in the years since the war have had many a financial struggle to keep going. Problex families do not evoke the same sympathy as either the physically or the mentally handicapped; nevertheless they exist in our society and apparently will continue to do so. We have therefore an obligation to treat and support them as we do the people who are handicapped in other ways.

\section{Westminster Hospital}

This week Westminster Hospital is celebrating its 250th anniversary. On 14 January 1716 four men-Henry Hoare, banker ; Robert Witham, vintner ; William Wogan, writer ; and the Reverend Patrick Coburn-sat down together at St. Dunstan's Coffee House in Fleet Street to discuss their concern over the sick poor of Westminster. From this small beginning sprang not only the foundation of Westminster Hospital but also that of St. George's Hospital at " High Park Corner "-or, as we now know it, Hyde Park Corner. This second foundation arose as a result of disagreement between members of the Westminster Board of Trustees about the merits of two rival sites for the expanding infirmary. At page 156 of this issue of the B.M.7. Dr. J. G. Humble draws on his forthcoming book Westminster Hospital 1716$1966^{1}$ to tell the eventful story of Westminster Hospital's first 250 years. The anniversary celebrations include \&

1 To be published shortly by Pitman Medical Publishing Company Brit. med. F., 1949, 2, 229. 